\title{
Notes
}

\section{Notes to Introduction}

1 In this book I use the terms 'ideals' and 'desires' interchangeably to convey what it is that citizens would ideally like to see from parties.

2 In order to disaggregate the influence of partisan cues it would be necessary to pose practically every question in relation to a specific party and parties in general. This means that a question such as 'In your opinion, when parties develop their policy positions, how often do they think about the following groups?' would need to be disaggregated to ask 'In your opinion, when [the Labour Party/Conservative Party/Liberal Democrat Party/Green Party/UK Independence Party/Scottish National Party/ Plaid Cymru and parties in general] develop their policy positions, how often do they think about the following groups?' Whilst allowing the survey to detect partisan influences, this approach is exceedingly expensive, time-consuming and repetitious. With an average survey question costing $£ 300$ for a single variation, specifying different parties would quickly escalate the cost to thousands of pounds for a single question. Moreover, questions that have seven or more variants require significant time from the respondent and due to their repetitive nature are likely to gather information of lower quality, as individuals tire of engaging with the nuances of each option. Respondents may also struggle to differentiate consistently between their views of multiple parties (many of which they may be unfamiliar with). For this reason, the Party Survey did not gather data on views of specific parties.

3 The survey was piloted twice prior to submission to YouGov in two focus groups: one with professional service staff and students at the University of Sheffield, and one with a group of stay-at-home parents. In both cases respondents were asked to complete the survey and talk through any problems they encountered and any ambiguities that arose. The conceptual meaning of questions was also examined, by asking respondents 


\section{Notes}

to explain what they thought they were being asked and how this conditioned their response. In addition, the survey was piloted online with YouGov before being sent out. Fifty responses were sought and initial data was used to test the validity of scalar measures.

4 For more information on recruitment to the deliberative workshops, see Appendix 2.

\section{Notes to Chapter 1}

1 Data taken from Eurobarometer, 87.3 (May 2017).

2 The precise wording of the question was: 'I would like to ask you a question about how much trust you have in certain institutions. For each of the following institutions, please tell me if you tend to trust it or tend not to trust it.'

3 The question was worded as follows: 'Some people say that political parties in [country] care what ordinary people think. Others say that political parties in [country] don't care what ordinary people think. Using the scale on this card (where ONE means that political parties care about what ordinary people think, and FIVE means that they don't care what ordinary people think), where would you place yourself?'

4 Respondents were able to choose between the following options in answering this question: 'nearly all interested in votes rather than people's opinions', 'most just interested in votes', 'some just interested in votes', 'most interested in opinions' and 'nearly all interested in opinions'.

5 The precise wording of the question was as follows: 'Some people say that political parties are necessary to make our political system work in [country]. Others think that political parties are not needed in [country]. Using the scale on this card (where ONE means that political parties are necessary to make our political system work, and FIVE means that political parties are not needed in [country]), where would you place yourself?' This was asked only in the 1996-2001 module of the survey and was not included in more recent modules. The CSES database is accessible at https://www.gesis.org/en/services/data-analysis/ international-survey-programs/cses (last accessed 24 February 2020).

\section{Notes to Chapter 2}

1 The possible responses included 'Don't know'. For the analysis, responses of 1 and 2 were collapsed ('Parties should use things like opinion polls to find out what the people want and then act on the results, even if this goes against what parties think is in the public interest'), as were scores 


\section{Notes}

of 3 and 4 ('Parties should act on their view of what is in the public interest, even if this might go against what opinion polls suggest the public want').

2 The possible responses included 'Don't know'. Again, for the analysis, responses of 1 and 2 were collapsed ('It is more important to have parties that stick to their principles, even if this means not following public opinion'), as were scores of 3 and 4 ('It is more important to have parties that follow public opinion, even if this means not sticking to their principles').

3 The options were randomised for respondents, but kept consistent for the next question. Responses were again on a $1-4$ scale $(1=$ Strongly disagree, $2=$ Disagree, $3=$ Agree, $4=$ Strongly agree) and there was a 'Don't know' option.

4 The precise question wording here was: 'Thinking about different people and institutions in British politics, please use the following scale to say how much you personally trust each of the following. 0 means you do not trust them at all, and 7 means you have complete trust'. Responses reported here are for 'Political Parties' but additional institutions were also presented to respondents.

5 When it comes to modelling approaches like this, it could be that the chosen variables do not capture a very select group of people driving the result. However, this seems unlikely for two related reasons: (1) these sociodemographic and attitudinal variables are standard across multiple studies that address related issues such as voting behaviour; and (2) the overall group of dissatisfied respondents is large enough to make this improbable. This is a general issue of dissatisfaction, not one driven by highly educated partisans for instance.

6 The options were randomised for respondents, but kept consistent for the next question. Responses were on a $1-5$ scale $(1=$ Almost never, $2=$ Less than half of the time, $3=$ About half the time, $4=$ More than half the time, $5=$ Almost all of the time) and there was a 'Don't know' option.

7 For their responses participants were asked to select one of: Very often; Sometimes; Rarely; Never. There was also a 'Don't know' option.

8 The question wording was: 'How often would you say that parties change their positions to reflect what people want?' and again for their responses participants were asked to select one of: Very often; Sometimes; Rarely; Never; 'Don't know'. 


\section{Notes to Chapter 3}

1 It should be noted that the opinions gathered here concern perceptions of the participatory opportunities offered to engage with parties themselves. This chapter does not therefore consider citizens' attitudes towards participating in the wider political system through parties, but instead concentrates on monitoring citizens' views of engaging with parties themselves.

2 Supporter networks are the low-cost mechanisms by which individuals can gain rights within a party without having to sign up for full membership.

3 There was also a 'Don't know' option.

4 The precise question wording was as follows:

To what extent do you agree or disagree with the following statements?

When people like me get involved in political parties, we can really have an impact on what parties say and do.

When people like me get involved in political parties, we should be able to have an impact on what parties say and do.

There are better ways of bringing about change in society than getting involved with political parties.

Political parties provide a way for ordinary people to come together to change the country.

The order of presentation of these options was randomised for respondents. The responses were on the following scale:

$1=$ Strongly disagree, $2=$ Disagree, $3=$ Neither agree nor disagree, $4=$ Agree, $5=$ Strongly agree. 'Don't know' was also an option.

5 This analysis focuses on those who choose to affiliate and does not, therefore, include those with no affiliation and no interest in engaging with parties.

6 This point became evident in survey question testing, where large numbers of respondents selected 'Don't know'. For this reason, the decision was taken not to interrogate general perceptions of party participation.

7 The four-point scale was $1=$ Not at all important, $2=$ Not very important, $3=$ Fairly important, $4=$ Very important. 'Don't know' was also an option.

8 The options were ordered as follows: (1) Get involved in a group within a party that has shared interests; (2) Get involved with a party locally; (3) Get involved in party activities generally; (4) Get involved with a party nationally; (5) Get involved in a group within a party that has shared characteristics. 


\section{Notes to Chapter 4}

1 The precise question wording was as follows:

You answered X. How well do you feel that parties today currently do these things?

Run the country/Represent those who voted for them

Very well

Fairly well

Not very well

Not well at all

Don't know

2 It should be noted that the number of respondents indicating a preference for judging in accordance with representation was somewhat smaller, but still large enough to allow the answers to be split.

3 The precise question wording was as follows:

When parties are in government, which of the following statements best describes your opinion of how parties do the following things?

Deliver promised policies

Deliver good policy outcomes

Manage the day-to-day running of government

Deal with crises

The above options were randomised across respondents. Responses were on a scale of 1-4: $1=$ Parties do this extremely well and no improvements could be made, 2 = Parties mainly do this well, but small improvements could be made, $3=$ Parties tend not to do this well and a lot of improvements could be made, $4=$ Parties don't do this at all well and huge improvements could be made, Don't know.

4 Respondents were presented with two statements and asked to indicate where they positioned themselves on a four-point scale where 1 indicated strong agreement with the statement 'It is more important for parties to govern in the interests of the whole nation' and 2 indicated slight agreement, whereas 3 indicated slight agreement with the statement 'It is more important for parties to govern in the interests of specific groups' and 4 indicated strong agreement. 'Don't know' was also an option.

5 The precise question wording was as follows:

When parties govern, they can make decisions by thinking about different things. Please rank these phrases to show what you think parties currently think about the most, where 1 is what parties think about the most and 3 is what parties think about the least.

Whether a decision fits with the party's principles and objectives

Whether a decision will gain the party votes in an election

Whether a decision is supported by evidence and independent advice 


\section{Notes}

These options were randomised across respondents, but then made to give consistent rankings of $1-3$.

\section{Notes to Chapter 5}

1 Respondents were asked:

To what extent do you agree or disagree with the following statements:

There is not much difference between what a party promises and what it actually does when it wins an election.

Political parties are more interested in winning elections than in governing afterwards.

Political parties spend too much time bickering with each other.

\section{Notes to Chapter 6}

1 If, for example, those with unrealised desires were all supporters of the UK Independence Party (UKIP) or of the Green Party, then it is unlikely that parties that do not want to court appeal from those groups would be interested in engaging in these ideas. In practice, however, parties across the spectrum have an interest in appealing to older voters and those with low levels of trust. 